ISSN 2089-8673

Jurnal Nasional Pendidikan Teknik Informatika (JANAPATI)

Volume 1, Nomor 1, Maret 2012

\title{
PENGARUH PENERAPAN PEMBELAJARAN INTERACTIVE ENGAGEMENT (IE) BERBANTUAN LEMBAR KERJA SISWA (LKS) TERHADAP HASIL BELAJAR SISWA KELAS XI SMA NEGERI 3 SINGARAJA TAHUN AJARAN 2010/2011
}

\author{
Oleh \\ I Gede Partha Sindu, Ketut Agustini, Made Windu Antara Kesiman \\ Jurusan Pendidikan Teknik Informatika \\ Universitas Pendidikan Ganesha \\ email: eghee2006@gmail.com,dekndu@yahoo.com
}

\begin{abstract}
ABSTRAK
Tujuan dari penelitian ini adalah untuk (1) mengetahui pengaruh penerapan pembelajaran Interactive Engagement berbantuan lembar kerja siswa (LKS) terhadap hasil belajar untuk materi Microsoft Access siswa kelas XI SMA Negeri 3 Singaraja dan (2) mengetahui respon siswa terhadap penerapan pembelajaran Interactive Engagement (IE) berbantuan lembar kerja siswa (LKS) untuk materi Microsoft Access siswa kelas XI SMA Negeri 3 Singaraja

Jenis penelitian ini adalah penelitian eksperimen semu. Populasi penelitian ini adalah siswa SMA Negeri 3 Singaraja. Sampel penelitian ini adalah siswa kelas XI IPA 2 dan XI IPA 3 SMA Negeri 3 Singaraja semester ganjil tahun ajaran 2010/2011 sebanyak 70 orang. Rancangan penelitian yang digunakan adalah Post Test Only with Non Equivalent Control Group Design. Pada akhir pembelajaran kedua kelas sampel diberi tes dengan menggunakan instrumen yang sama yang telah diuji validitas, reliabilitas, taraf kesukaran, dan daya pembeda soal. Pengumpulan data dilakukan dengan metode tes pilihan ganda satu jawaban benar. Metode tes dilakukan untuk memperoleh data nilai akhir setelah diberi perlakuan pada kelompok eksperimen. Sebelum dianalisis dilakukan uji prasyarat yang meliputi uji normalitas dan uji homogenitas. Kemudian data dianalisis menggunakan uji t. Sedangkan untuk respon menggunakan metode angket yang dianalisis secara deskriptif kualitatif.

Berdasarkan perhitungan uji normalitas dan uji homogenitas varians yang hasilnya adalah kedua data baik kelompok eksperimen maupun kelompok kontrol berdistribusi normal dan mempunyai varians yang homogen. Hasil dari perhitungan uji homogenitas ini selanjutnya digunakan dalam uji hipotesis dengan teknik statistik uji-t dengan taraf signifikansi $5 \%$ dan derajat kebebasan $n_{1}+n_{2}-2$. Dari perhitungan uji-t didapat $t_{\text {hitung }}=3,978$ dan $t_{\text {tabel }}=1,995$. Karena $t_{\text {hitung }}>t_{\text {tabel }}$ maka dapat disimpulkan bahwa terdapat pengaruh yang signifikan terhadap penerapan pembelajaran Interactive Engagement (IE) berbantuan lembar kerja siswa (LKS) terhadap hasil belajar untuk materi Microsoft Access siswa kelas XI SMA Negeri 3 Singaraja. Sedangkan untuk respon siswa sebanyak 44,12 \% siswa memberikan respon sangat positif, 52,94\% siswa merespon positif dan 2,94\% siswa merespon cukup positif.
\end{abstract}


ISSN 2089-8673

Jurnal Nasional Pendidikan Teknik Informatika (JANAPATI)

Volume 1, Nomor 1, Maret 2012

Kata-kata kunci : Interactive Engagement (IE) berbantuan lembar kerja siswa (LKS), hasil belajar, respon siswa.

THE INFLUENCE OF INTERACTIVE ENGAGEMENT (IE) BASED ON STUDENT WORK SHEET UPON THE XI GRADE STUDENTS' ACHIEVEMENT OF SMAN 3 SINGARAJA IN THE ACADEMIC YEAR 2010/2011

\begin{abstract}
The aims of this research were (1) to know the influence of Interactive Engagement based on student work sheet upon the XI grade students' achievement of SMAN 3 Singaraja in learning Microsoft Access and, (2) to know the students' response toward the use of Interactive Engagement based on student work sheet upon the XI grade students' achievement of SMAN 3 Singaraja in learning Microsoft Access.

The type of this research was a quasi experimental. The populations of this research were the students' of SMAN 3 Singaraja. The sample of this research were the students' of XI Science 2 and XI Science 3 of SMAN 3 Singaraja in the academic year 2010/2011, both groups consisted of 70 students. The experimental design was Post Test Only with Non Equivalent Control Group Design. In the end of treatment, both groups were given a test using same instrument which have been tested its validity, reliability, difficulty level, and question differentiation power. The data collection was done by using 1 appropriate answer multiple choice test method. The methodological of the test was done for getting final score after the experiment group was given some treatments. Before analyzing the data, it had to analyze the data parametrically which consisted of normality and homogeneity test. Then the data was analyzed using t-test. For response, the researcher used questionnaire method which was analyzed using descriptive qualitative.

Based on the calculation of normality and homogeneity of variance test, the result showed that experimental and control group had normal distribution and homogeneity of variance. The result of homogeneity test was used in calculation the t-test with significant value of $5 \%$ and degree of freedom was $n_{1}+n_{2}-2$. The result of t-test showed that $t$-count $=3.978$ and $t$-table $=1.995$. Because of $t$-count is higher than t-table, it showed that there was a significant influence in the use of Interactive Engagement based on student work sheet upon the XI grade students' achievement of SMAN 3 Singaraja in learning Microsoft Access. The students responded positively,
\end{abstract}


ISSN 2089-8673

Jurnal Nasional Pendidikan Teknik Informatika (JANAPATI)

Volume 1, Nomor 1, Maret 2012

$44.12 \%$ students gave very positive response, $52.94 \%$ students gave positive response, and $2.94 \%$ students gave enough positive respond.

Key words : Interactive Engagement based on the student work sheet, learning achievement, students' response.

\section{Pendahuluan}

Pemerintah Indonesia melakukan berbagai upaya untuk meningkatkan kualitas pendidikan. Salah satu upaya yang dilakukan oleh pemerintah adalah dengan penyempurnaan kurikulum. Penyempurnaan kurikulum ini diharapkan dapat meningkatkan kualitas pendidikan di Indonesia. Kurikulum yang sedang diterapkan saat ini yaitu Kurikulum Tingkat Satuan Pendidikan (KTSP), sehingga diharapkan dapat terjadi perubahan paradigma pembelajaran dari teacher centered (berpusat pada guru) menjadi student centered (berpusat pada siswa).

Berdasarkan hasil observasi yang dilakukan di SMA Negeri 3 Singaraja didapat bahwa hasil belajar siswa tahun ajaran 2008/2009 dan tahun 2009/2010 menunjukkan nilai dibawah Kriteria Ketuntasan Minimal (KKM) yang ditetapkan sekolah sebesar 75. Rendahnya hasil belajar tersebut disebabkan karena belum optimalnya penggunaan komputer, proses pembelajaran yang diterapkan di sekolah cenderung berpusat pada guru, dan belum optimalnya penggunaan sumber belajar seperti Lembar Kerja Siswa (LKS) bagi siswa. Pada proses pembelajaran TIK di sekolah, sering dijumpai apabila siswa diberikan masalah tampak bahwa siswa cenderung tidak menggunakan pertimbangan dalam memecahkan masalah, dan siswa juga kurang seksama dalam membaca soal sehingga kinerja pemecahan masalah siswa masih tergolong rendah. Dalam memecahkan suatu permasalahan, guru cenderung mengarahkan siswa untuk mendapatkan hasil (jawaban yang benar) tanpa memperhatikan proses atau kegiatan yang dilakukan siswa selama pencarian solusi dari permasalahan tersebut. Gambaran sistem belajar seperti ini tampaknya kurang efektif dalam hal menumbuhkan minat siswa terhadap pelajaran itu sendiri. Sehingga untuk itu perlu diadakannya perubahan model pembelajaran yang baru dan lebih 
ISSN 2089-8673

Jurnal Nasional Pendidikan Teknik Informatika (JANAPATI)

Volume 1, Nomor 1, Maret 2012

inovatif untuk meningkatkan kemampuan siswa dalam menguasai materi/pokok bahasan pembelajaran secara teoritik dan praktik.

Salah satu model pembelajaran inovatif yang dapat diterapkan adalah model pembelajaran Interactive Engagement (IE). Model pembelajaran IE merupakan model pembelajaran yang berorientasi pada siswa (student centered), dimana siswa dilibatkan langsung dalam berbagai jenis kegiatan pembelajaran di kelas. Model pembelajaran IE membuat siswa saling berinteraksi dalam berbuat dan berpikir (hand on and minds on) yang menghasilkan umpan balik secara langsung terhadap materi pelajaran yang diberikan.

Berdasarkan hal tersebut di atas, penulis akan mencoba untuk mengkaji lebih jauh tentang pengaruh penerapan pembelajaran Interactive Engagement (IE) berbantuan lembar kerja siswa (LKS) terhadap hasil belajar untuk materi Microsoft Access siswa kelas XI SMA Negeri 3 Singaraja tahun ajaran 2010/2011.

\section{Metode Penelitian}

Jenis penelitian ini adalah Penelitian Tindakan Eksperimen Semu (Quasi Experimental). Populasi dalam penelitian ini adalah seluruh siswa kelas XI semester ganjil (1) SMA Negeri 3 Singaraja tahun ajaran 2010/2011 sebanyak 7 kelas dengan jumlah 234 siswa. Sampel penelitian ini dipilih dengan teknik "random sampling" sehingga didapat dua kelas sebagai sampel yaitu kelas XI-IPA 3 sebagai kelas eksperimen dan kelas XI-IPA 2 sebagai kelas kontrol dengan desain penelitian "Post Test Only with Non Equivalent Control Group Design”. Adapun data yang ingin dikumpulkan dalam penelitian ini yaitu: (1) hasil belajar siswa dengan menggunakan tes hasil belajar (tes obyektif) di akhir pelajaran, (2) respon siswa terhadap penerapan pembelajaran Interactive Engagement (IE) dengan cara memberikan kuisioner (angket respon) pada siswa yang diterapkan pembelajaran tersebut.

Untuk tes hasil belajar yang akan diberikan pada kelompok eksperimen dan kontrol, terlebih dahulu tes tersebut diujicobakan dan dianalisis. Hasil dari analisis uji instrumen tersebut dipakai untuk tes hasil belajar di akhir pembelajaran kelompok 
ISSN 2089-8673

Jurnal Nasional Pendidikan Teknik Informatika (JANAPATI)

Volume 1, Nomor 1, Maret 2012

eksperimen dan kelompok kontrol. Adapun teknik yang dipakai untuk menganalisis uji instrumen adalah uji validitas, uji reliabilitas, daya beda item dan tingkat kesukaran butir tes yang masing-masing rumusnya adalah sebagai berikut.

a. Uji Validitas

$$
\gamma_{p b i}=\frac{M_{p}-M_{t}}{S_{t}} \sqrt{\frac{p}{q}}
$$

Kriteria butir soal dalam kategori valid jika $\gamma_{p b i}-$ hitung $>r_{p b i}$ - Tabel pada taraf signifikan 5\%.

b. Uji Reliabilitas

$$
r_{1.1}=\left(\frac{n}{n-1}\right)\left(\frac{s^{2}-\sum p q}{s^{2}}\right)
$$

Tes hasil belajar yang dapat diterima sebagai perangkat tes adalah yang berada pada kategori derajat reliabilitas sedang $\left(0,40<r_{1.1} \leq 0,60\right)$, tinggi $\left(0,60<r_{1.1} \leq 0,80\right)$, dan sangat tinggi $\left(0,80<r_{1.1} \leq 1,00\right)$.

c. Daya Beda Item

$$
D=\frac{B_{A}}{J_{A}}-\frac{B_{B}}{J_{B}}=P_{A}-P_{B}
$$

Soal yang dapat digunakan adalah soal yang memiliki indeks deskriminasi 0,4 sampai 0,7

d. Tingkat Kesukaran Butir Tes

$$
P=\frac{B}{J S}
$$

Untuk tes standar, biasanya butir yang ditoleransi dianjurkan memiliki rentangan: $0,30 \leq P \leq 0,70$ 
ISSN 2089-8673

Jurnal Nasional Pendidikan Teknik Informatika (JANAPATI)

Volume 1, Nomor 1, Maret 2012

Setelah tes hasil belajar diberikan pada kelompok kontrol dan kelompok eksperimen dan angket respon siswa, selanjutnya data yang didapat dari tes hasil belajar dan respon siswa tersebut dianalisis. Adapun teknik analisis yang digunakan adalah sebagai berikut.

1. Uji Normalitas Data

$$
X^{2}=\sum \frac{\left(f_{0}-f_{h}\right)^{2}}{f_{h}}
$$

Keterangan :

$X^{2}$ : Chi Kuadrat

$f_{0}$ : Frekuensi observasi

$f_{h}$ : Frekuensi yang diharapkan

Kriteria pengujian pada taraf signifikan $5 \%$ data terdistribusi normal jika: $X^{2}{ }_{h i t}<X^{2}$ tabel

2. Uji Homogenitas Varians

$$
F_{\text {hitung }}=\frac{\text { Variansterbesar }}{\text { Variansterkecil }}
$$

Kriteria pengujian pada taraf 5\% adalah kedua sampel homogen, jika $F_{\text {hitung }}<$ $F_{\text {tabel }\left(\alpha\left(n_{1}-1, n_{2}-1\right)\right)}$

\section{Uji Hipotesis}

$$
t_{h i t}=\frac{\bar{X}_{1}-\bar{X}_{2}}{\sqrt{\frac{\left(n_{1}-1\right) s_{1}^{2}+\left(n_{2}-1\right) s_{2}^{2}}{n_{1}+n_{2}-2}\left(\frac{1}{n_{1}}+\frac{1}{n_{2}}\right)}}
$$

\section{Keterangan:}

$\mathrm{X}_{1}$ : nilai rata-rata skor post test kelompok eksperimen

$\mathrm{X}_{2}$ : nilai rata-rata post test kelompok kontrol

$\mathrm{n}_{1}$ : banyak siswa kelompok eksperimen

$\mathrm{n}_{2}$ : banyak siswa kelompok kontrol

$\mathrm{s}_{1}$ : simpangan baku kelompok eksperimen

$\mathrm{s}_{2}$ : simpangan baku kelompok kontrol.

4. Respon Siswa

Untuk mengetahui respon siswa terhadap penerapan pembelajaran Interactive Engagement (IE) berbantuan lembar kerja siswa, terlebih dahulu 
ISSN 2089-8673

Jurnal Nasional Pendidikan Teknik Informatika (JANAPATI)

Volume 1, Nomor 1, Maret 2012

ditentukan rata-rata $(\overline{\boldsymbol{X}})$ respon siswa yaitu jumlah skor respon siswa dibagi dengan jumlah siswa. Rata-rata ini kemudian digolongkan berdasarkan kriteria penggolongan respon siswa yang digolongkan menjadi 5 kriteria yaitu sangat positif, positif, cukup positif, kurang positif dan sangat kurang positif. Untuk menggolongkan respon siswa tersebut, terlebih dahulu dicari nilai dari mean ideal (MI) dan standar deviasi ideal (SDI) dapat dilakukan dengan rumus sebagai berikut.

$$
\begin{aligned}
& \mathrm{Mi}=1 / 2(\text { skor tertinggi }+ \text { skor terendah }) \\
& \mathrm{Sdi}=1 / 6(\text { skor tertinggi }- \text { skor terendah })
\end{aligned}
$$

\section{Hasil dan Pembahasan}

Berdasarkan analisis statistik yang telah dilakukan mengenai uji normalitas data, uji homogenitas varians, dan uji-t (hipotesis) sesuai dengan rumus yang dipaparkan di atas, maka diperoleh hasil uji normalitas data pada kelompok eksperimen dengan model pembelajaran IE mendapatkan hasil 6,98 dan kelompok kontrol dengan model pembelajaran DI mendapatkan hasil 4,69 dengan nilai tabel 11,070. Untuk homogenitas varians dari kedua kelompok tersebut hasilnya adalah 1,02 dan nilai tabelnya 1,77. Karena hasil dari normalitas data dan homogenitas varians lebih kecil dari nilai tabel sehingga datanya berdistribusi normal dan homogen. Setelah melakukan uji hipotesis didapat bahwa hasil dari $t_{\text {hitung }}$ dan $t_{\text {tabel }}$ dengan taraf signifikan 5\% masing-masing yaitu 3,978 dan 1,995.

Secara deskriptif hasil analisisnya menyatakan bahwa skor rata-rata kelompok eksperimen dengan model pembelajaran IE dan kelompok kontrol dengan model pembelajaran DI setelah diberikan post-test adalah 32,21 dan 28,67. Berdasarkan kedua skor tersebut, terlihat bahwa skor rata-rata kelompok eksperimen lebih besar dibandingkan dengan skor rata-rata kelompok kontrol. Dilihat dari perhitungan uji normalitas dan homogenitas hasilnya tidak jauh berbeda, dimana kedua kelompok tersebut memiliki data yang berdistribusi normal dan homogen. 
ISSN 2089-8673

Jurnal Nasional Pendidikan Teknik Informatika (JANAPATI)

Volume 1, Nomor 1, Maret 2012

Berdasarkan seluruh penemuan yang diperoleh baik dari secara deskriptif maupun berdasarkan analisis statistik uji-t, maka dapat diambil suatu keputusan bahwa pembelajaran Interactive Engagement (IE) berbantuan lembar kerja siswa (LKS) pada pokok bahasan Microsoft Access memberikan pengaruh yang lebih baik dibandingkan dengan pembelajaran konvensional. Hal ini dikarenakan siswa lebih mudah menentukan dan memahami konsep-konsep yang sulit dengan mendiskusikan bersama temannya. Melalui diskusi akan terjalin komunikasi dan terjadi interaksi dengan siswa lain dengan saling berbagi ide serta memberi kesempatan pada siswa untuk mengungkapkan pendapatnya. Dengan belajar secara berkelompok siswa yang lebih pandai dapat memberikan bantuan kepada siswa yang kurang pandai. Ini dapat menumbuhkan motivasi belajar bagi siswa yang akan berdampak positif pada hasil belajar mereka.

Kendala yang ada dari penelitian ini adalah skor hasil belajar siswa pada kelompok dengan model pembelajaran IE belum sepenuhnya mampu mencapai kategori sangat baik dan perbedaan skor rata-rata kelompok eksperimen dengan skor rata-rata kelompok kontrol tidak terlalu tinggi. Kendala ini disebabkan oleh: (1) rentang waktu belajar di sekolah yang singkat sehingga tidak mengakomodasi pelaksanaan kegiatan pembelajaran berbantuan LKS secara utuh. (2) siswa belum terbiasa dengan LKS yang berorientasi pada model pembelajaran IE yang diberikan. (3) siswa belum terbiasa melakukan presentasi atau mengungkapkan pendapat di depan kelas.

\section{Penutup}

Berdasarkan rumusan masalah, tujuan, hasil penelitian dan pembahasan seperi yang telah diuraikan di depan, maka dapat ditarik kesimpulan sebagai berikut: (1) terdapat pengaruh yang signifikan penerapan model pembelajaran Interactive Engagement (IE) berbantuan lembar kerja siswa (LKS) terhadap hasil belajar untuk materi Microsoft Access siswa kelas XI SMA Negeri 3 Singaraja, (2) Respon yang 
ISSN 2089-8673

Jurnal Nasional Pendidikan Teknik Informatika (JANAPATI)

Volume 1, Nomor 1, Maret 2012

diperoleh dari penerapan pembelajaran Interactive Engagement (IE) berbantuan lembar kerja siswa (LKS) adalah positif.

Dari hasil simpulan tersebut di atas, maka disarankan kepada para guru maupun pihak sekolah diharapkan bersedia menggunakan model pembelajaran IE sebagai salah satu alternatif model pembelajaran yang sesuai dengan paradigma konstruktivisme dan mengacu pada KTSP. Untuk para pembaca yang berminat mengadakan penelitian lebih lanjut, selain membandingkan hasil belajar siswa bisa juga membandingkan aspek kemampuan pemecahan masalah siswa, aspek kemampuan berpikir kritis siswa, serta aspek pemahaman siswa menggunakan model pembelajaran IE. Selain itu bagi para peneliti lain agar memperhatikan kendalakendala yang peneliti alami sebagai bahan pertimbangan untuk perbaikan dan penyempurnaan pelaksanaan penelitian.

\section{Daftar Pustaka}

Arikunto, S. 2005. Manajemen penelitian. Jakarta: PT Rineka Cipta.

Cahyadi, V. 2003. "The Effect of Interactive Engagement Teaching Method to Student Understanding of Introductory Physics at the Faculty Engineering, University of Surabaya, Indonesia". http:/surveys.canterbury.ac.nz (diakses pada tanggal 8 Juni 2010).

Hake, R. R. 1998. "Interactive-Engagement versus Traditional Methods: A sixThousand-Student Survey of Mechanics Test Data for Introductory Physics Courses". American Journal of Physics. 66 (1). 64-74.

Melly Soliastini, Putu. 2010. Pengembangan Lembar Kerja Siswa (LKS) Untuk Materi Microsoft Access di Kelas XI SMA Negeri 3 Singaraja. Skripsi (tidak diterbitkan). Jurusan Pendidikan Teknik Informatika Universitas Pendidikan Ganesha (Undiksha) Singaraja.

Pari Purna V, I Gede. 2009. Pengaruh Model Pembelajaran IE Terhadap Kemampuan Pemecahan Masalah Siswa Kelas VIII SMP Negeri 3 Singaraja Tahun Ajaran 2008/2009. Skripsi (tidak diterbitkan). Jurusan Pendidikan Fisika Universitas Pendidikan Ganesha (Undiksha) Singaraja.

Sugiyono. 2010. Statistika Untuk Penelitian. Bandung: CV. Alfabeta. 